Article

\title{
The Value of Money: Funding Sources and Philanthropic Priorities in Twentieth-Century American Mission
}

\author{
David W. Scott ${ }^{(D)}$ \\ Global Ministries, The United Methodist Church, 458 Ponce De Leon Ave NE, Atlanta, GA 30308, USA; \\ dscott@umcmission.org
}

Received: 9 February 2018; Accepted: 4 April 2018; Published: 10 April 2018

\begin{abstract}
At the turn of the twentieth century, Western missionaries and mission organizations sought to develop financial strategies that would facilitate the further expansion of the Western mission enterprise. Three such strategies emerged: an increasingly sophisticated, corporatized approach to fundraising by mission boards; faith missions that shifted the economic risks associated with fundraising from mission agencies to missionaries; and self-supporting missions that cultivated economic funding available in the mission field. Each of these strategies had different implications for power configurations in the mission enterprise and allowed the values and views of different groups to prevail. The board approach empowered mission executives and large donors. The faith mission approach empowered missionaries and supporters with a conservative theology. The self-supporting mission approach made missionaries arbiters among a variety of competing interests. This economic approach to the study of mission provides new insights into the complex and contested power arrangements involved in Western foreign mission that extend beyond those gained from traditional political and cultural analyses.
\end{abstract}

Keywords: mission; fundraising; mission boards; faith mission; self-supporting mission; missionaries; money; power

\section{Introduction}

The colonial model of the Western missionary enterprise was an expensive one. While Christian missionaries have adopted financial strategies since the time of Paul or Jesus himself, the level of resources required for the extension of Christianity has varied across time and place. Christians have understood the nature of the Christian mission variously, for a variety of cultural and theological reasons, and these differing concepts of mission have had implications for the resources necessary to carry them out.

One of the distinguishing features of emerging Western modernity was its large resource consumption relative to traditional societies. Western missionaries sought to extend a model of Christianity and Western culture predicated on this level of resource consumption to societies without a corresponding level of resource development. Thus, Western missions required significant financial support for a wide variety of costs: missionary salaries; the building of churches, schools, hospitals, and other buildings; the importation of Bibles, hymn books, teaching supplies, printing presses, pianos, organs, and other Western material objects; shipping for Western missionaries and their goods; salaries of Bible women and native pastors; and administrative costs for mission societies and other funding and supporting groups in home countries (Scott 2013). Samuel Capen expressed a typical Western view of mission when he said, "While it is true that 'money cannot save the world,' yet, humanly speaking, it is equally true that 'the world cannot be saved without money.'” (Capen 1910, p. 471). 
The expense of the colonial Western model of mission combined with its successes, albeit limited ones, led to a financial crisis in Western mission by the beginning of the twentieth century. Westerners had proven able to successfully establish missions overseas and recruit some level of native converts, though generally a rather small number. These limited successes whetted Westerners' appetite to send out more missionaries and engage in more mission. Since Westerners had proven capable of establishing missions in some locations abroad, they wanted to do so in more places. Since they had only limited success in recruiting converts in the places where they were established, they wanted to intensify efforts in established areas of mission work.

Both the desire for mission in more places and more mission in current places meant a need for more resources, both in terms of personnel and money. Identifying adequate personnel was a challenge for the Western mission enterprise, but organizations such as the Student Volunteers for Mission bolstered the number of Westerners committing themselves to go overseas.

Money, however, was a much larger challenge. By the beginning of the twentieth century, many mission societies in the United States and Europe found themselves in the position of having insufficient funds to fully support the mission work they would have liked to do, and at times insufficient funds to fully support the mission work in which they were already engaged. Commission VI of the 1910 World Missionary Conference remarked, "The investigation by this Commission reveals the fact that there is not a leading Missionary Society in Europe or America that is properly supported. In the judgment of the officers of all of these Societies, work that ought to be done is left undone, open doors are unentered, and even what has been begun is often disastrously neglected because of the insufficiency of the financial support." (World Missionary Conference 1910, p. 146).

The question, then, for Western mission leaders was how to continue to expand Western missions in the face of these financial constraints. Three main responses emerged to this question: the corporatization of mission agencies, the rise of faith missions, and the rise of self-supporting missions. This paper will examine all three before making the argument that, implicit in these three answers to this question, were different configurations of power and thus different sets of values shaping the nature and history of mission. Because of the connection between financing, power, and values, this paper will conclude by asserting that further research into mission financing can help scholars better understand the complex and changing constellations of agendas involved in Western mission work.

\section{The Corporatization of Mission Agencies}

One response to the problem of insufficient funds for Western mission work was for mission agencies to double-down on the existing model of Western missions that depended on donations collected from Westerners in the home base. To make up for shortfalls, mission agencies sought to increase these collections through increasingly sophisticated fundraising techniques and borrowed money when expenses exceeded income.

As other scholars have noted, Western mission agencies were at the forefront of the development of increasingly sophisticated charitable fundraising techniques in the late nineteenth and early twentieth centuries (Dawson 2000; Hill 1985, pp. 95-99; Lisbon 2016; Rabe 1978). Such techniques involved new forms of giving, such as directed giving, stock gifts, and annuities. It involved new groups to encourage giving, including women's groups, children's mite societies, and businessmen's fellowships.

When the amount of money raised still wasn't enough to cover mission agencies' commitments, they borrowed to make up the difference. Mission agencies structured that borrowing in a variety of ways, including bank loans and direct bonds. Retiring such debt then became the incentive for yet another set of fundraising techniques and goals.

Money raised from Western donors or borrowed by mission agencies went toward almost all aspects of the mission enterprise. It paid for the salaries and operating expenses of the mission agencies themselves. It paid for missionary salaries and the salaries of native pastors and Bible women. It helped construct buildings for churches, schools, hospitals, printing presses, and agricultural centers 
and then paid for the equipment appropriate to each one. Money from Western donors paid to ship missionaries and Western material goods to the mission field. There was no aspect of the Western missionary enterprise that could not be paid for by Western donors.

This was the great advantage of the board approach - money from Western donors, especially money collected through apportionment plans or undesignated gifts could be used for whatever aspect of mission that mission agency leaders thought best. Apportionment funds and undesignated gifts thus gave mission executives considerable power to shape mission expenditures and thus mission according to their own values and sense of what was needed in the work. Input from other denominational leaders and missionaries (and perhaps native Christians indirectly through missionaries) could influence these values, but ultimately mission executives made the decisions.

Of course, not all gifts to mission agencies were undesignated. Indeed, the new fundraising techniques created a larger role for designated giving, as it was an effective way to engage donors. While mission executives and missionaries sought to educate home base donors about mission needs and thus influence their designated giving, donors ultimately controlled where they gave their gifts. Thus, designated giving allowed Western home base donors a significant amount of power to shape the mission enterprise according to their values, even when these values were not well-aligned with or even contradicted the values of missionaries and mission agency executives.

Moreover, heightened mission expenses meant that mission agencies increasingly courted large donations from big donors, such as John D. Rockefeller, Sr., who thus had significant influence in how their money was spent. Support from a large donor, or lack thereof, could determine whether or not mission projects happened. Moreover, large donors could propose their own mission projects, whether or not these projects had been requested by missionaries or mission leaders, and incentivize missionaries and mission leaders to adopt these projects by offering to fund them.

\section{The Rise of Faith Missions}

Early faith missions also, for the most part, continued to rely on Western home base donors for most of their donations. The major financial innovations of faith missions initially were to shift the burden of fundraising risks from the mission agency to the missionary and to alter the way in which Western donors were cultivated (Lindsell 1962). The faith mission approach to mission was pioneered by the great English missionary Hudson Taylor and his China Inland Mission. Taylor drew on the thought of George Müller, the founder of several orphanages in Bristol, England, who sought to rely on faith in God for economic provision for his organizations. Many others picked up faith principles from Taylor and used them to start their own mission organizations (Fiedler 1994).

Most traditional mission agencies assumed the risk of lower than expected (or hoped for) fundraising income themselves. Thus, as indicated above, when fundraising fell short, agencies borrowed to make up the difference. Early faith missions shifted the risks of lower than expected fundraising to the missionaries. Faith missionaries were not guaranteed a set salary, unlike board-sponsored missionaries. Instead, they were promised a share in what the sponsoring agency raised, however much that was. If the sponsoring agency had a good fundraising year, missionaries were paid well. If fewer donations were received, missionaries made do with less. This shift in risk incentivized missionaries to control expenditures and would eventually push some in the direction of self-supporting missions, but these were effects rather than objectives of this financial policy.

In addition to this shift in risk, most (though not all) faith missions eschewed the direct fundraising techniques of mission agencies in favor of indirect techniques. These indirect techniques involved publicizing the work generally, but not making specific financial requests as part of that publicity. Some faith groups made mention of specific financial needs; others did not. This indirect approach to fundraising appealed especially to those donors turned off by the increasingly corporatized approach to fundraising that mission agencies were taking (Svelmoe 2008, p. 64).

As with Western support given to traditional mission boards, Western money given to faith missions could theoretically be used for anything, at least when undesignated. The advantage to faith 
mission approaches to fundraising that made no mention of specific needs was that a larger percentage of gifts given were undesignated. Faith missionaries who made mention of specific needs were more likely to receive designated gifts, though since missionaries decided which needs to mention, they had a large role in shaping these designations. Moreover, faith missions tended to have relatively little administrative structure, meaning there were fewer mission leaders to direct donations received. Thus, the faith mission approach was one which gave the missionaries the largest say in how resources were used.

The large role for missionaries in making resource decisions is another reason women played a significant part in early faith missions. Single women were often willing to live on smaller salaries than men, and the level of financial and programmatic control by individual missionaries was appealing to women, who were often marginalized in denominational mission board approaches to mission. As Dana Robert has commented, "Almost any individual who had the faith to raise her own funds was a potential candidate for a faith mission in the early years." (Robert 1997, p. 197).

Since missionaries had a large say in how resources were used and because they were not guaranteed a particular income, missionaries tended to make certain decisions about expenditures. Traditionally such decisions have been seen as theologically motivated, but it is important to note how economic considerations reinforced theological convictions. Faith missionaries tended to avoid sponsoring large institutions such as universities and hospitals, not just because of theological convictions about the primacy of evangelism, but because such institutions required significant amounts of capital and ongoing operating expenses. Such costs looked like much riskier endeavors when missionaries were the ones who would be on the hook if Western donations fell short. Education was often a component of faith work, especially for women, as Robert has documented (1997), but small schools aimed at basic literacy could be operated fairly cheaply, with little required beyond missionaries' salaries. For the most part, faith missionaries directed Western gifts to their own salaries and such goods (Bibles, books, and bikes, e.g.,) as they themselves used in their evangelistic work.

\section{The Rise of Self-Supporting Missions}

The third approach to the problem of financing mission has gotten less attention in scholarly literature and, when it has, has often been lumped together with faith missions. Nevertheless, while faith missions and self-supporting missions would eventually converge, the two had significantly different beginnings with significantly different answers to the question of mission financing.

If Hudson Taylor was the most significant proponent of faith missions, it was another Taylor-William Taylor-who did the most to promote self-supporting missions. Taylor asserted that Christian missions should be able to proceed without any financial support from the home base, instead relying on resources cultivated on the field. Taylor identified donations from Westerners living in colonies abroad, tent-making business income for missionaries, and support from colonial government as important sources of such resources (Taylor 1882, pp. 44-59). Donations from natives, both Christian and non-Christian, could be another significant source of resources on the mission field, though Taylor focused less on these sources of funding. Ultimately, Taylor would concede a role for Western donations in paying for missionary travel. Other missionaries who practiced self-support were less doctrinaire about avoiding Western support than Taylor. Thus, this approach was not incompatible with Western donations; however, it prioritized cultivating resources on the mission field.

Since this approach to mission financing involved not one source but several heterogeneous sources of money, the uses of such money and power configurations involved varied widely. Donations from Western Christians living in colonies went to support church facilities for their own worship, which could also then house worship for converts; salaries for their own pastors, who might then also engage in mission work; and often the salaries of native evangelists. Tent-making business income could be used for whatever the missionary earning the money wanted to use it for. This made it an especially useful source of funds for missionaries, though it required significant time and effort to earn such money. Schools and hospitals could be a special type of tent-making mission that underwrote 
part of their costs through fees while also serving larger missional goals. Government donations sponsored school construction and operation and land for schools, churches, and other infrastructure. Non-Christian natives would support school and hospital facilities that they and their communities could use regardless of religious affiliation. Native Christians paid for their native pastors and church buildings, though were seldom asked (or offered) to contribute to other categories of mission expense (Scott 2013).

Thus, different forms of self-supporting mission gave different groups power, allowing for the expression of their distinct values. Complicating this situation is the fact that many self-supporting missions drew from several of these sources. Missionaries decided how to balance the various objectives and values of different groups of funders, giving them power, but they were also constrained by these values. Missionaries were thus central in this model, but significantly limited by others' interests. These constraints and the complexity of combining varied financial arrangements were a significant argument against adopting this approach to mission. Moreover, the level of resources available locally varied widely based on the level of economic development in that locality. Hence, this approach was more successful in areas of mission wherein a newly globalized economy was expanding and generating new wealth. Taylor's own missions struggled in some spots, such as Angola and the Congo, where the global economy was limited (Tzan 2018).

\section{Conclusions}

A basic conviction of this paper has been that whoever controls the funding for Christian mission has power within that mission, and that power can be used to express the values, interests, and beliefs about mission of the group controlling funding. This basic insight, however, played out differently in each of the three approaches outlined above, both at the turn of the twentieth century when they were developed, and in the decades since.

As indicated above, corporate mission agencies granted financial power to mission executives and Western donors, especially well-to-do large donors such as the Rockefellers. Mission executives and Western donors initially used this power to conduct a form of mission that reflected Western cultural sensibilities and was comfortable with Western colonial expansion. Both mission executives and well-to-do donors, however, were elite groups with elite values. Large donors were part of an economic elite. Mission executives were well-educated relative to average Christian parishioners.

Thus, as the twentieth century went on, the views of mission executives tended to evolve with the changing theological and missiological understandings of liberal Christianity. This led to a gradual estrangement between mainline denominational agencies and the people in their pews, as the work of denominational agencies reflected the increasingly theologically liberal values of mission executives and major donors such as the Rockefellers. As a consequence, many mainline mission agencies have either been dramatically reduced in scope due to lack of support and/or have faced competition from newer, more conservative groups, as in the case of the formation of the Mission Society for United Methodists in 1984 to compete with the General Board of Global Ministries of The United Methodist Church.

Another new set of competitors for denominational mission societies, both mainline and evangelical, has been humanitarian relief agencies. As Harold Lindsell noted of mission society fundraising techniques, "[D]enominational promotion stresses the program, the humanitarian, the less personal." (Lindsell 1962, p. 213) That approach has proven vulnerable to fundraising competition from non-mission religious humanitarian relief agencies, who make similar appeals but can claim to offer greater expertise and specialization in such work. Michael Jaffarian reports that more money now goes to religious relief and development work than evangelism and discipleship (Jaffarian 2008, p. 37).

By contrast, faith missions reflected the values of missionaries and Western donors, especially those of an anti-institutional bent. As noted above, missionaries had financial as well as theological incentives to focus their work primarily on evangelism rather than more expensive wholistic approaches to mission. Western donors with an anti-institutional attitude also tended to be more 
theologically conservative. Thus, faith missions became a movement predominantly associated with conservative theology, both because of the premillennial convictions of early faith mission leaders and because its financial structure privileged conservative voices and an evangelism-only approach to mission.

Faith missions were an extremely successful approach, and they continue strongly. For decades, three of the seven largest American missionary-sending organizations have been interdenominational faith missions. The other four are evangelical denominational boards (Jaffarian 2008, p. 37). Nonetheless, faith missions have developed considerably since their early days. They have become more sophisticated in their organizational schema, reflecting a larger trend in American evangelicalism toward an embrace of evangelical-run institutions (Carpenter 1990). They have also moved toward a holistic understanding of mission, a moved enabled in part by their increase in size and organizational complexity and the concomitant increase in financial means, in part by the influence of converts and experience on missionary views of mission, and in part by shifting theologies of mission among Western evangelicals generally. In all these regards, faith missions have developed in ways consistent with their funding sources.

Self-supporting missions could reflect the values of a variety of groups, depending on how they were self-supported. Business as mission allowed missionaries' values to prevail, since they could do whatever they wanted to with money they earned. Donations from colonial governments and Westerners abroad promoted colonial values, mainly associated with the extension of a peaceful colonial civil society and the cultivation of good workers for colonial governments and businesses. Donations from non-Christian natives promoted aspects of globalizing modernity that were seen as beneficial to native communities, mainly education and medicine. Donations from Christian natives promoted the value of indigenous-led Christianity.

Perhaps the difficulty of balancing this set of competing values is why self-supporting missions were not a more popular option at the turn of the twentieth century. Moreover, none of the values promoted in self-supporting mission were the values of home-base Christians, meaning the model was less attractive for those home-base Christians, since it did not give them much power in shaping the nature of mission work. Limited home base mobilization affected missionary recruitment. Self-supporting mission might have faded from view, had not faith missionaries, who were empowered by the system of faith missions, found that several aspects of self-supporting missions also increased the financial power of missionaries to shape mission according to their values. Thus, self-supporting missions, including business as mission models, have had a resurgence in recent decades, especially among Christian groups that in earlier decades would have affiliated most closely with faith missions.

Of course, the three approaches indicated here are idealized types. Many missions combined funding from a variety of sources and thus had to balance these various and at times competing interests.

For all approaches, though, there is an overriding lesson for historians: Because it involved the power to shape what types of mission work were and were not undertaken, the economic history of mission finances and fundraising has as much to tell us about the tensions involved in Western mission history as does political or cultural history. While the story of the competing interests of missionaries, Western colonial authorities, home base Christians, native Christian converts, and native non-Christians has been told primarily through the history of political machinations and shifting cultural understandings, the same story could be told (with fresh insights) through the history of financial support and therefore control of mission work. To cite just one possibility for such research, an approach to more fully understanding how native agency was engaged in the growth of World Christianity could look at the role of native donations in the finances of mission and church groups. While this paper has given just a brief glimpse into the sorts of investigations possible along this line of economic history, I hope it is generative of more work in this vein.

Acknowledgments: No external funds supported the production of this manuscript. 
Conflicts of Interest: The author is employed by a mission board. That mission board had no role in the design of the study; in the collection, analyses, or interpretation of data; in the writing of the manuscript, and in the decision to publish the results.

\section{References}

Capen, Samuel B. 1910. The responsibility of laymen for the promotion of the foreign missionary enterprise. In Students and the Present Missionary Crisis: Addresses Delivered before the Sixth International Convention of the Student Volunteer Movement for Foreign Missions, Rochester, New York, December 29, 1909, to January 2, 1910. New York: Student Volunteer Movement for Foreign Missions, pp. 471-76, OCLC: 860433003.

Carpenter, Joel A. 1990. Propagating the faith once delivered: The fundamentalist missionary enterprise, 1920-1945. In Earthen Vessels: American Evangelicals and Foreign Missions, 1880-1980. Edited by Joel A. Carpenter and Wilbert R. Shenk. Grand Rapids: William B. Eerdmans Publishing Co., pp. 92-132. ISBN 0802804020.

Dawson, David G. 2000. Funding mission in the early twentieth century. International Bulletin of Missionary Research 24: 155-58, DLC: 81641167. [CrossRef]

Fiedler, Klaus. 1994. The Story of Faith Missions: From Hudson Taylor to Present Day Africa. Oxford: Regnum Books International, ISBN 1870345185.

Hill, Patricia R. 1985. The World Their Household: The American Woman's Foreign Mission Movement and Cultural Transformation, 1870-1920. Ann Arbor: University of Michigan Press, ISBN 0472100556.

Jaffarian, Michael. 2008. The statistical state of the North American Protestant missions movement, from the Mission Handbook, 20th Edition. International Bulletin of Missionary Research 32: 35-38, DLC: 81641167. [CrossRef]

Lindsell, Harold. 1962. Faith missions since 1938. In Frontiers of the Christian World Mission since 1938: Essays in Honor of Kenneth Scott Latourette. Edited by Wilber C. Harr. New York: Harper \& Brothers, pp. 189-230, OCLC: 222901958.

Lisbon, Scott. 2016. 'Faith in Money': Mission Movement Fundraising and American Philanthropy, 1860-1930. Doctoral Dissertation, Emory University, Atlanta, GA, USA.

Rabe, Valentin H. 1978. The Home Base of American China Missions, 1880-1920 (Harvard East Asian Monographs 75). Cambridge: Harvard University Press, ISBN 0674405811.

Robert, Dana L. 1997. American Women in Mission: A Social History of Their Thought and Practice. Macon: Mercer University Press, ISBN 0865545499.

Svelmoe, William Lawrence. 2008. A New Vision for Missions: William Cameron Townsend, the Wycliffe Bible Translators, and the Culture of Early Evangelical Faith Missions, 1917-1945. Tuscaloosa: The University of Alabama Press, ISBN 0817315934.

Scott, David William. 2013. The Crossroads of Earth and Heaven: Methodism's Malaysia Mission and the Making of the Global World, 1885-1915. Ph.D. dissertation, Boston University, Boston, MA, USA.

Taylor, William. 1882. Ten Years of Self-Supporting Missions in India. New York: Phillips \& Hunt, OCLC: 462767358. Tzan, Douglas. 2018. Bookmakers, Schoolteachers, and Hippopotamus Hunters: The Theological and Social Origins of Entrepreneurial Missions. Paper presented at American Social of Church History Winter Meeting, Washington, DC, USA, January 4-7.

World Missionary Conference. 1910. World Missionary Conference, 1910, Report of Commission VI: The Home Base of Missions. Edinburgh: Oliphant, Anderson \& Ferrier, New York: Fleming H. Revell Company, OCLC: 9583489.

(c) 2018 by the author. Licensee MDPI, Basel, Switzerland. This article is an open access article distributed under the terms and conditions of the Creative Commons Attribution (CC BY) license (http://creativecommons.org/licenses/by/4.0/). 